Dorota Gacka

Warszawa

\title{
Całościowe opracowania Kodeksu lubińskiego (poł. XIX w. - pocz. XXI w.)
}

Od niedawna w Narodowej Bibliotece Cyfrowej zwanej Poloną dostępny jest w domenie publicznej skan Kodeksu lubińskiego ${ }^{1}$, czyli kodeksu Jana z Dąbrówki. Obok obrazów mamy zamieszczone podstawowe wiadomości dotyczące tej księgi, mianowicie: datę powstania (1430-1440), opis fizyczny (356 kart, rozmiar $31 \times 21,5 \mathrm{~cm}$ ), charakterystykę oprawy (tektura, półskórek, XIX w.), język zabytku (łaciński) i sygnaturę (rkps 3002). Przedstawiona jest także jego zawartość i podstawowa literatura z nim związana. Właśnie tym wskazówkom bibliograficznym pragniemy się przyjrzeć, aby pokazać, jak stopniowo narastała wiedza dotycząca kodeksu. Czynimy to z dwóch powodów. Pierwszy jest osobisty: wchodzimy w krag szerszych badań nad wspomnianym rękopisem i dlatego zapoznajemy się ze stanem wiedzy na jego temat. Drugi zaś - to dobro czytelników zaglądających na stronę internetową ze skanem zabytku. Pragniemy, aby mieli oni zgromadzone w jednym miejscu wszystkie dotychczasowe opisy kodeksu i nie musieli ich szukać w rozproszonych i nie zawsze łatwo dostępnych kompj+endiach wiedzy. Ponieważ każda praca naukowa wymaga wyznaczenia zakresu badań i ograniczenia materiału, uwagę poświęcimy wyłącznie całościowym opisom kodeksu, chociaż różne uwagi dotyczące księgi można spotkać w opracowaniach poświęconych poszczególnym zabytkom w niej zawartym. Niektóre z tych dzieł mają tak obszerną literaturę, że jej przytaczanie mogłoby rozsadzić ramy naszej pracy. Ostrzegamy również, że lektura poniższego artykułu nie będzie łatwa, jako że za przedmiot bierzemy sobiJje suche opisy bibliograficzne. Przetwarzanie zaś tego typu informacji nie jest równie wdzięczne

${ }^{1}$ Zob. http://www.polona.pl/item/264647/3 [14.07.2014]. Kodeksu tego nie należy mylić z Kodeksem lubińskim z 1353 roku, zawierającym Legendę obrazowa o św. Jadwidze, obecnie przechowywanym w The J. Paul Getty Museum w Malibu. 
jak analiza i interpretacja wydarzeń historycznych, niemniej jednak i takie prace należy od czasu do czasu wykonywać.

Najwcześniejsze uwagi dotyczące zabytku pojawiają się u Augusta Bielowskiego - w jego Wstępie krytycznym do dziejów Polski. Dzieło to bardzo odbiega od dzisiejszego stanu wiedzy i na dodatek zawiera zupełnie nie trafioną terminologię. Sam Bielowski pisze, że wprowadził ją po starannym przebadaniu źródeł i nie towarzyszyło mu przy tym pragnienie nowatorstwa. $Z$ powodów, które wyłożył w innym miejscu, nazwał „Dzierzwę Miorszem; Marcina Gala Gawłem; Kadłubka Wincentym Bogusławicem; Godzisława Baszkę Godysławem Paskiem; bezimiennego notaryusza Beli Gwidonem z Kolumny"'. Znajdujemy u niego również takie formy, jak Lęchia, Lęchici, Waregowie, Wętycze. Zdecydował się na nie ze względu na brzmienie języka Nestora ${ }^{3}$. Tak więc dzieło Bielowskiego należy czytać z dużą ostrożnością i krytycyzmem, do czego skłania już choćby sam spis treści. Oto bowiem jak przedstawia się zawartość księgi I, stanowiącej przegląd źródeł do dziejów Polski: „I) Kronika lęchicka, II) Roczniki polskie, III) Miorsza kronika Lęchitów i Polaków, IV) Kronika Gawła mnicha i Michała kanclerza, V) Latopis Nestora, VI) Kronika Kozmy pragskiego, VII) Mateusza kronika Lęchitów i Polaków, VIII) Kronika Wincentego Bogusławica, zwanego Kadłubkiem, IX) Kronika Bogufała, X) Godysława Paska kronika Lęchitów i Polaków, XI) Gwidona z Kolumny historya o siedmiu xiążętach węgierskich, XII) Masud'ego Łąka złota i kopalnie klejnotów"4.

Pierwsza z notatek o Kodeksie lubińskim pojawia się we Wstępie krytycznym w rozdziale III: Miorsza kronika Lęchitów i Polaków. Bielowski przedstawia zawartość kodeksu (jednak nie po kolei i nie w pełni), jego opis fizyczny, datowanie, lokalizację. Relacjonuje również, w jaki sposób dowiedział się o zabytku, kreśląc tym samym obraz swoich kontaktów z innymi badaczami i życia naukowego XIX-wiecznych historyków. Według uczonego interesujący nas kodeks, darowany Warszawskiemu Towarzystwu Przyjaciół Nauk przez Józefa Ksawerego Kuropatnickiego, dostał się do Petersburga, gdzie znajdował się w Bibliotece Publicznej pod sygn. $19 \mathrm{IV} \mathrm{fol}$. Tam z woluminu korzystał książę Henryk Lubomirski, kurator naukowy Zakładu Ossolińskich, sporządzający dla tej instytucji odpisy z różnych cennych manuskryptów. To właśnie Lubomirski w 1845 r. przybliżył Bielowskiemu w liście wymieniony kodeks i przysłał tekst pierwszej strony. Później kolega Bielowskiego, Jan Szlachtowski,

${ }^{2}$ August Bielowski, Wstęp krytyczny do dziejów Polski, Lwów 1850, s. IV.

${ }^{3}$ Zob. tamże.

${ }^{4}$ Tamże, k. nlb. 
przywiózł mu z podróży naukowej do Petersburga odpis kroniki Miorsza (Mierzwy) wraz z dopełnieniami i różnicami obu kodeksów: Kuropatnickiego i lubińskiego. Dzięki otrzymanym od kolegów informacjom Bielowski sporządził następujący opis rękopisu:

Lubiński (sc. rękopis) zawiera kronikę Miorsza wraz z dopełnieniami od k. 1-26; dalej rocznik benedyktyński, genealogię Piastów, szereg biskupów krakowskich, kronikę Wincentego zwanego Kadłubkiem, kronikę Godysława Paska i kronikę Jana z Czarnkowa, archidyakona gnieźnieńskiego. Jest ten rękopism papierowy, w formacie arkusza; rok, w którym go pisano, niewiadomy; starszy atoli nie jest nad wiek $\mathrm{XV}^{5}$.

W drugiej nocie pojawiającej się w tym samym dziele autor powtarza przekazane wcześniej wiadomości, dodaje jednak do nich także parę nowych. Wskazuje, że interesujący nas rękopis pochodził z klasztoru benedyktyńskiego w Lubinie (ówczesne województwo brzesko-kujawskie), miał 542 stronice liczbowane i nową oprawę z zielonej skóry. Oprócz tego Bielowski daje opis zawartej w kodeksie kroniki Wincentego Kadłubka oraz towarzyszącego jej komentarza (nie wie jeszcze, że jego autorem był Jan z Dąbrówki). Kronika ta z komentarzem i glosami, według słów uczonego, znajduje się na trzecim miejscu w rękopisie (s. 69-356). Zapisana jest w jednej kolumnie, wyraźnie, dużymi literami. Początkowe litery zapisano na czerwono. Na jednej stronicy mieści się od 20 do 24 wersów. Kronika ma wyraźny podział na cztery księgi, ale w trzech pierwszych $\mathrm{z}$ nich rozdziały rzadko są oznaczone na brzegach kart. Komentarz do kroniki również mieści się na marginesach i na małych karteczkach dołączonych w różnych miejscach. Wyjątek stanowi tylko przedmowa Legenti mihi. W komentarzu zwracają uwagę liczne przekreślenia, jakby autor na bieżąco opracowywał jego wersję. To zaś, co nie zostało usunięte, zgadza się z komentarzem znajdującym się $\mathrm{w}$ rękopisie Stanisława Augusta ${ }^{6}$.

Trzecia wzmianka o Kodeksie lubińskim zawarta we Wstępie krytycznym Augusta Bielowskiego poświęcona jest znajdującemu się w rękopisie przekazowi kroniki Godzisława Baszki, którego historyk zwie Godysławem Paskiem. Zabytek ten pojawia się, zdaniem uczonego w rękopisie jako czwarty w kolejności (s. 359-460). Został zapisany w jednej kolumnie, drobnymi literami. Tytuły rozdziałów podkreślone są na czerwono. Tekst kroniki jest okrojony, bo zaczyna się ona dopiero od roku 1027

\footnotetext{
${ }^{5}$ Tamże, s. 30-31.

${ }^{6}$ Zob. tamże, s. 130.
} 
- rozdziałem De secundo Mesthkone. Ale ma też dopełnienia: po opisie odzyskania Gdańska przez Bolesława w 1272 roku, zgodnym z przekazami kodeksów Stanisława Augusta i Sędziwoja z Czechła, następują noty o różnych zdarzeniach aż do roku $1306^{7}$.

Swoje konstatacje ze Wstęu krytycznego Bielowski powtarza w II i III tomie Pomników dziejowych Polski, dorzucając gdzieniegdzie jakieś nowsze uwagi. Na przykład w przedmowie do wydania Kroniki Mierzwy dodaje, że kompilacja ta umieszczona jest $\mathrm{w}$ interesującym nas rękopisie na pierwszym miejscu (s. 1-51). Kończy się słowami: „et deinde omnia mala orta sunt. Explicit Cronica Polonorum". Zapisano ją starannie, z ozdobami, ,bez przedziałek". Na marginesach wynotowano rozdziały ksiag biblijnych, z których zostały zaczerpnięte cytaty umieszczone w tekście. Tu też wyliczono 43 pokolenia od Noego do Józefa i tyleż pokoleń od Józefa do Wandala ${ }^{8}$.

Przedmowa do kroniki Mistrza Wincentego nie wnosi praktycznie nic nowego, może poza uwagą: „text średnia fraktura, komentarz kursywa, a drobniuchno między wierszami glosy"9. Wydawca w dalszym ciagu nie zdaje sobie sprawy, że ma do czynienia z kodeksem Jana z Dąbrówki: „Cały kodex pisan był według wszelkiego podobieństwa w klasztorze benedyktyńskim w miasteczku Lubiniu [...]"10. Podobnie we wstępie do Kroniki Boguchwata i Godystawa Paska znajdujemy te same konstatacje, nowościa jest jedynie zdanie: ,zawiera text dość poprawny i zupełniejszy niż w Sommersbergu"11.

Nieco inaczej przedstawia się przedmowa Jana Szlachtowskiego do Kroniki Janka z Czarnkowa. Z opracowania, oprócz znanych faktów dowiadujemy się też, że rękopis lubiński zapisany jest pismem dość dużym, ale nieczytelnym, aż po stronę 466 do linii 6 rozdziału Kroniki Janka z Czarnkowa. W tym miejscu następuje zmiana ręki - na piszącą równie dużymi literami, ale wyraźniej. Wcześniej, po kronice Paska (Baszki), od strony 461 ciagną się roczniki jak u Sommersberga (od s. 95, w. 43 do s. 96, w. 40), różniące się jednak od tego wydania. Potem następuje krótka wiadomość o śmierci Łokietka i koronacji Kazimierza Wielkiego. Na s. 464 zaczyna się rozdział Kroniki Janka z Czarnkowa o rządach Kazimierza Wielkiego, podobnie jak u Sommersberga (s. 97, w. 30). Odtąd aż do s. 527 mamy całe dzieło Janka. Dalej pojawiają się zapiski

\footnotetext{
7 Tamże, s. 172-173.

${ }^{8}$ Zob. MPH, t. II, s. 160-161.

${ }^{9}$ Tamże, s. 207.

${ }_{10}$ Tamże.

${ }^{11}$ Tamże, s. 462.
} 
jak u Sommersberga ${ }^{12}$. Kończą się one na s. 528, słowem „Gneznensis”. Tekst Kroniki Janka z Czarnkowa zawiera te same błędy i opuszczenia co rękopisy: wilanowski i włocławski, pozbawiony jest jednak rozdziałów 45 i 85, które w tamtych manuskryptach się znajdują ${ }^{13}$.

Jan Szlachtowski jako pierwszy dostarcza nam też wiadomości o ostatnich dwóch utworach zawartych w kodeksie, mianowicie o Elegii na śmierć Kazimierza Jagiellończyka i o Exordium ordinis Cruciferorum. Stwierdza, że na s. 528 zaczyna się Epicedion Elegiacum penthametrum M[agist]ri Laurentii Corvini Novoforensis editum in nobili funere serenissimi Casimiri olim regis P[oloniae] M[agni] D[ucatus] L[ithuaniae] R[ussiae] Pr[ussiae]que domini et haeredis. Pierwsze słowa tekstu brzmią: „Regia Sarmatiae resecavit...”, a ostatnie - „ordine tecta nigris” (s. 533). Po nich następuje (do s. 541) drugi poemat tegoż autora, zaczynający się wyrazami: „Eximium nobis es Kazimire decus...”. Na ostatnich stronicach rękopisu (541-542) mamy zapiski dziejowe z lat 1226 i 1234. Pierwszy mówi o sprowadzeniu Krzyżaków przez Konrada Mazowieckiego, drugi - o napadzie na Prusy zorganizowanym przez książąt: Leszka Białego, Henryka Brodatego, Świętopełka pomorskiego pospołu z Krzyżakami, zakończonym wielką rzezią Prusów ${ }^{14}$.

Przedmowa Augusta Bielowskiego do wydania Rocznika franciszkańskiego krakowskiego w t. III Pomników dziejowych Polski do stanu wiedzy nie wnosi nic nowego ${ }^{15}$. Uczony poprawnie identyfikuje Rocznik małopolski i pisze, że następuje on w kodeksie lubińskim bezpośrednio po kronice Mierzwy z jej dopełnieniami i zajmuje strony 51-57. W przekazie dostrzega kilkakrotną zmianę pisma. Podaje, że do roku 1061 włącznie pisany jest fraktura, dalej - do roku 1103 - kursywa, po czym znów frakturą aż do 1203 r. W końcu wiadomość o Mistrzu Wincentym została zapisana znacznie późniejszą ręka, ale jeszcze w XV wieku ${ }^{16}$.

Kilka zabytków znajdujących się w kodeksie lubińskim między Kronika wielkopolska a Kronika Janka z Czarnkowa Bielowski uznaje za Rocznik kujawski. W przedmowie do wydania tegoż rocznika pisze, że przechował się on w kilku rękopisach, które jednak różnią się między sobą. W trzech przekazach, mianowicie: wilanowskim, wrocławskim i sieniawskim, zaczyna się on krótką wzmianką o Leszku Białym, a kończy opisem bitwy pod Płowcami, stoczonej przez Łokietka z Krzyżakami. W kodek-

${ }^{12}$ F.W. Sommersberg, Silesiacarum Rerum Scriptores Aliquot Adhuc Inediti, Lipsiae 1730 , t.II, s. 154.

${ }^{13}$ Tamże, s. 610-611.

${ }^{14}$ Zob. MPH, t. II, s. 611.

${ }^{15}$ Zob. MPH, t. III, s. 46.

${ }^{16}$ Tamże, s. 139. 
sie lubińskim rocznik ten wpisany jest bardzo starannie na k. 461-463, po Kronice Paska (Baszki), a przed Kronika Janka z Czarnkowa. Nie ma tu jednak notatki o Leszku Białym, podobnie jak w kodeksie królewieckim; być może była to więc wzmianka osobna, która pierwotnie do tego rocznika nie należała. Znajdujemy ją jednak w kodeksie Sędziwoja (s. 213) po zapiskach mieszanych, tu ma osobny tytuk: Sequitur de Lestcone filio Cazimiri. W rękopisie lubińskim Rocznik kujawski zaczyna się pochwałą Bolesława Wstydliwego, a kończy krótką wiadomością o śmierci Łokietka i wstapieniu na tron Kazimierza Wielkiego. Nad poszczególnymi ustępami zostały umieszczone nadpisy frakturą. Nie ma ich jednak nad ustępem pierwszym. Mamy też nadpisy na marginesach górnych, dodane prawdopodobnie przez kopistę. Rocznik ten ciagnął się zapewne nieco dalej i kończył wiadomością o wstapieniu na tron Ludwika Węgierskiego. Wskazują na to kodeksy ottoboniański i królewiecki ${ }^{17}$.

Przedmowa do wydania Rodowodu xiqżat polskich dowodzi, że Bielowski zidentyfikował ten zabytek poprawnie. Według jego słów, jest on zapisany w rękopisie lubińskim na s. 58-65. Genealogia została wyprowadzona od Graka (Grakcha) aż do roku 1462. Rodowód skreślono doraźnie, z licznymi pomyłkami i poprawkami. Jednak obok wyraźnych błędów pojawiają się daty i szczegóły, które nie występują gdzie indziej, a są godne zastanowienia. Ten sam tekst z podobnymi pomyłkami i tylko niewielkimi odmiankami lub opuszczeniami znajduje się w rękopisie Biblioteki Uniwersytetu Jagiellońskiego w Krakowie pod sygn. 358. Manuskrypt ten powstał w drugiej połowie XV wieku, na papierze w formacie czwórki ${ }^{18}$.

Kolejnych wiadomości o interesującym nas kodeksie dostarcza w roku 1910 Józef Korzeniowski w sprawozdaniu z podróży naukowych do Petersburga odbytych w latach 1891-1892 i 1897. Historyk opis fizyczny rękopisu wzbogaca uwagami, że pisany był on ,siedmioma rękami XV wieku, na 333 kartach liczbowanych” oraz że na grzbiecie posiada napis „Kronika Dirswy, Kadłubka, Bogufała i Anonyma Archidyak. Gnieźn." ${ }^{19}$. Uczony noty na pierwszej karcie pergaminowej, poczynione ręką Lelewela:

Rękopism Lubieński, w nim trzy rękopisma: I. Kronika Dirswy z Annałami zwykle przy niej będącemi, a nie wykończonemi tu od str. 1 do 68. - II. Kronika Kadłubka z jej komentarzem wielo dopiskami zmienionym od str. 69 do

${ }^{17}$ Tamże, s. 204.

${ }^{18}$ Tamże, s. 280.

19 J. Korzeniowski, Zapiski z rękopisów Cesarskiej Biblioteki Publicznej w Petersburgu i innych bibliotek petersburskich. Sprawozdanie z podróży naukowych odbytych 1891-1892 i 1907 r., Kraków 1910 (Archiwum do Dziejów Literatury i Oświaty w Polsce, 11), s. 83 . 
358. - III. Kronika Bogufała $\mathrm{z}$ jego kontynuatorem Baszkonem i kontynuacją dalszą od str. 359 do 460 oraz Kronika Archidjakona Gnieźnieńskiego, obie bez początków od 461 do końca ${ }^{20}$,

bierze za dopiski Bielowskiego, do końca nie ma jednak pewności, więc przy jego nazwisku stawia znak zapytania ${ }^{21}$. Dalej następuje charakterystyka zawartości rękopisu, pierwsza w dotychczasowej literaturze, w miarę poprawna, jednak w kilku miejscach skażona lekturą błędnych konstatacji Bielowskiego. Ponieważ do tego opisu będą się odnosiły wszystkie następne, a ponadto ponieważ bardzo dokładnie wyznacza on granice wszystkich zabytków zawartych w kodeksie, pozwalamy sobie przytoczyć ten wykaz w całości:

Rękopis zawiera roczniki i kroniki polskie, a mianowicie:

a) K. 1b: W górnej części strony: spis i tablica genealogiczna Piastów: «Choschisko / Pyaschk / Zemivid...» itd.; w dolnej części spis biskupów krakowskich (tz. Katalog II, wyd. W. Kętrzyński MPH III, 328 sq.: «Prochorius 969 ordinatur, 16 annis vixit...».

b) K. 2-26: tz. Kronika Mierzwy wraz z jej «dopełnieniem» oraz tz. «rocznikiem franciszkańskim krakowskim». Incip. «Ortum sive originem polonice gentis ab inicio mundi ego, qui sum incognominatus, talem in scripturis inveni...». Kończy się: «... Qui mortuus est [Leszek Czarny] in die beati Ieronimi anno domini MCCXXXVIII et demum omnia mala orta sunt in terra. - Explicit Cronica Polonorum. Cetera vide in annalibus: DCCCXCIX Arnolphus fuit...» itd. Por. następujące teksty: tz. Kronika Mierzwy i tz. Dopełnienie Mierzwy oraz tz. rocznik franciszkański krakowski, wyd. z tego kodeksu Bielowski, MPH II, 163-190, 283-438 (passim), III, 46-52.

c) K. 26-29: Rocznik tz. małopolski II Benedyktynów lubińskich od 899 do 1203 i 1216, wyd. Bielowski MPH II, 820-823; III, 140-164. Łączy się ten rocznik bezpośrednio w rękopisie z «dopełnieniem» kronik tz. Mierzwy. W jednym ciagu mianowicie po «Explicit - annalibus» (zob. wyżej) następuje: «DCCCXCIX Arnolphus fuit ultimus Imperator, quantum ad posteritatem magni Karoli...» itd. Por. Kętrzyński, O Roczniku Małopolskim [w:] RTPN X, 201-242, zob. str. 226.

d) K. 29b-34b: Genealogia królów polskich i domu Piastowskiego w formie tablic. Wyd. pt. «Rodowód xiążąt polskich», Bielowski, MPH III, 281-284.

e) K. 35-241: Kronika Mistrza Wincentego z prologiem, glosowana, z komentarzem: «Legenti mihi illas illustris Cassiodori». [...] Wyd. $\mathrm{z}$ tego rkpsu Bielowski, MPH II, 249-452.

\footnotetext{
${ }^{20} \mathrm{BN}$, rps 3002, k. 1r.

${ }^{21}$ Zob. J. Korzeniowski, dz. cyt., s. 83.
} 
f) K. 245-294b: Kronika wielkopolska (tz. Bogufała) od rozdziału: «De secundo Meschkone. Mortuus itaque magno Boleslao...» do końca. Wyd. Bielowski MPH II 484-598. Rozdziały poprzerzucane.

g) K. 295-329b. Następuje zbiór drobniejszych zapisek genealogicznych etc. Książąt pomorskich, tudzież Przemysława, Wacława, Władysława Łokietka, Kazimierza Wielkiego, Ludwika i Jagiełły; dalej tz. «rocznik kujawski» (wyd. Bielowski, MPH III, 206-212) z nagłówkami rozdziałów. Incip. «Anno Domini 1266 Illustris Boleslaus Pudicus, dux Cracoviensis et Sandomiriensis...». Następują rozdziały: «De morte Pudici Boleslai», «De Boleslai Mazoviensis assumptione» itd. - Po czem następuje kronika Jana z Czarnkowa (do końca), wyd. Bielowski, MPH II, 619-756, oraz część tz. «Spominek mieszanych», por. Bielowski, MPH III, 288 sqq.

h) K. 329b-332: Wiersze łacińskie (dystychy): «Epicedion elegiacum penthametrum magistri Laurencii Corvini Novoforensis editum in nobile funus Serenissimi Casimiri olim regis Polonie...» itd. Incip.: «Regia Sarmatiae resecavit stamina gentis / Effera tartareo parca sepulta solo...».

i) K. 333: Dwie zapiski z 1226 i 1234 - o ile mi się zdaje - nie wydane: «Anno domini 1226 Conradus, dux Mazowie, primus vocavit Cruciferos in subsidium sibi, quorum primus fuit frater Hermanus de Zalcza»; «Anno domini 1234 venerunt duces: Cunradus Mazowie, Lestko Albus Cracovie, Henricus cum barba Wratislavie et Swantopelcus Pomeranie et fundaverunt territorium Prussye, quod Resin (?) dicitur et vastaverunt illud multos ex Prutenis occidendo, contra quos venit exercitus Prutenorum et congressu facto victi sunt Pruteni. Swantopelcus, ut dux Pomeranie, cum suo exercitu preclusit fugam Prutenis, propter quod occisa fuerunt Prutenorum quinque milia». Cf. Długosz, Hist. Pol., sub $1234^{22}$.

Swoją charakterystykę zawartości rękopisu J. Korzeniowski kończy postulatem, który był realizowany w latach następnych. Pisze, że manuskrypt ten, jako jeden $\mathrm{z}$ najważniejszych dla polskiej historiografii średniowiecznej, zasługuje na dokładniejsze zbadanie. Wyniki tych naukowych dociekań nie pozostaną bez wpływu na uporządkowanie naszych źródeł średniowiecznych, co już zostało zapoczątkowane pierwszą częścią rozprawy Tadeusza Wojciechowskiego O rocznikach polskich $X-X V w^{23}$. Korzeniowski zaznacza, że jego opis, choć do tej pory najdokładniejszy, jest niewystarczający ${ }^{24}$.

${ }^{22}$ Tamże, s. 83-85.

${ }^{23}$ Tadeusz Wojciechowski, $O$ rocznikach polskich $X-X V$ w., „Pamiętnik Akademii Umiejętności w Krakowie. Wydziały Filologiczny i Historyczno-Filozoficzny”, t. IV, Kraków 1880, s. 144-233.

${ }^{24}$ Zob. J. Korzeniowski, dz. cyt., s. 85. 
W przypisach do swojej pracy historyk rozpatruje kwestię proweniencji kodeksu. Korzeniowski stwierdza, że nie zna powodów, dla których Bielowski uznaje, że rękopis pochodzi z biblioteki benedyktynów w Lubinie (Korzeniowski przytacza taką formę, jakiej użył Bielowski). W naszej literaturze manuskrypt jest zawsze nazywany lubińskim. Między 1815 a 1827 r. Józef Kuropatnicki darował go bibliotece Towarzystwa Przyjaciół Nauk, skąd w 1833 r. kodeks przeszedł do Cesarskiej Biblioteki Publicznej. Być może nazwano go lubińskim ze względu na to, że na s. 8 rękopisu, w Kronice Mierzwy, w miejscu, w którym mowa o miastach założonych przez Leszka III (MPH II, 179), nad słowem,,Lublin” widnieje glossa „Lubin”, nakreślona czerwoną farbą przez współczesnego kopisty (Bielowski, MS 15) 25 .

W przypisach poruszona jest także sprawa autorstwa Elegii na śmierćKazimierza Jagiellończyka. Korzeniowski uznaje ją za utwór Klemensa Janickiego - najwcześniejszy i nieznany ${ }^{26}$. Tu również wspomniany badacz dokonuje oceny pracy swego poprzednika: „Opis rękopisu wszędzie niedokładny i pełen sprzeczności u Bielowskiego"27.

Brygida Kürbis rękopis lubiński oglądała już w Bibliotece Narodowej. Znajdował się on tam wówczas pod sygn. 3149. Poza cechami wymienionymi przez wcześniejszych badaczy zwróciła uwagę na podwójną paginację z XVII i XIX w. W rozważaniach uczonej powróciła kwestia pochodzenia rękopisu - powołując się na autorytet Wojciecha Kętrzyńskiego, B. Kürbis uznała manuskrypt za własność profesora uniwersytetu krakowskiego, Jana z Dąbrówki. Droga jej rozumowania była następująca. Na wstępie mediewistka zauważyła, że określenie pierwotnej przynależności rękopisu jest trudne, ponieważ XIX-wieczna oprawa zatarła jego wcześniejszy wygląd. Mamy co prawda kartę ochronną w postaci pomarszczonego pergaminu, ale zachowały się na niej tylko nikłe ślady pisma, pochodzącego być może z XIV w. Po drugie, uczona zauważa, że pochodzenie nazwy „rękopism Lubieński” jest nieznane. Kętrzyński odrzucił ją, nie znalazłszy jakichkolwiek śladów własnościowych klasztoru w Lubiniu. Niemniej musiały istnieć jakieś podstawy do nadania takiego określenia. Brygida Kürbis widzi dwie możliwości: albo benedyktyni lubińscy byli ostatnimi właścicielami kodeksu w chwili kasaty klasztoru, albo też ktoś uznał, że znalazł zaginiony rękopis, który oglądał niegdyś Załuski w Lubiążu. W drugim wypadku trzeba by przyjąć pomyłkę Lubiąż - Lubiń, do której nieraz w badaniach dochodziło. Cennym odkry-

\footnotetext{
${ }^{25}$ Tamże.

${ }^{26}$ Tamże.

${ }^{27}$ Tamże.
} 
ciem uczonej jest notatka proweniencyjna na kartce wklejonej w środek manuskryptu, a oznaczonej liczbą 170. Mamy tu zapisane kursywą humanistyczną: „Libri ducti ex Posnania olim d. doctoris Bolanczki viginti numero inclusive quattuor librorum in humanioribus Senioris Chabyelski nepoti datorum" 28 , co stanowi wskazówkę, jak wyglądały najwcześniejsze losy kodeksu. Brygida Kürbis przyjmuje twierdzenie Kętrzyńskiego, że rękopis stanowił własność Jana z Dąbrówki. Podziela też spostrzeżenie swego poprzednika, że komentarz do Wincentego ma w kodeksie lubińskim postać oryginalnego brulionu. Na przynależność pisarza do środowiska krakowskiego może też wskazywać Wykaz biskupów krakowskich. Ponadto w tekście kroniki zwracają uwagę liczne podkreślenia fragmentów mówiących o Krakowie ${ }^{29}$.

Konstatacje uczonej dotyczące zasadniczych części kodeksu nie różnią się od ustaleń poprzedników. Ale jest też trochę nowych wiadomości. Po pierwsze uważa ona, że tablica genealogiczna Piastów i katalog biskupów krakowskich zostały wpisane na odwrocie pergaminu po uprzednim zmyciu pierwotnej treści ${ }^{30}$. To, co znajduje się między Kronika Dzierzwy a kroniką Wincentego z komentarzem Jana z Dąbrówki, określa jako rocznik obejmujaccy lata 889-1216, nazywany tutaj annales Karoli (s. 51-57). O dwuwierszu Ex virtute poli formata..., który znajduje się na dolnym marginesie w tymże roczniku, a który jest też znany z rękopisu wrocławskiego, pisze, że dystych ten nie łączy się w najmniejszym stopniu z tekstem ${ }^{31}$.

Dalej zauważa, że komentarz Jana z Dąbrówki został zapisany „śmiałą kursywą”, kronika Wincentego zaś - „minuskułą gotycką”. Poza tym przedstawiona przez mediewistkę charakterystyka brulionu nie różni się od opisów poprzednich ${ }^{32}$.

Przy Kronice wielkopolskiej, która w naszym kodeksie zaczyna się dopiero od rozdziału De secundo Mescone, B. Kürbis stwierdza, że brak tutaj śladów wydarcia . Odnajdujemy natomiast oznaki genealogicznych zainteresowań pisarza, który w sposób rysunkowy postanowił przedstawić ważniejsze fakty prawno-familijne. Wśród rzadkich glos na marginesach, odnotowujących przeważnie daty, mamy podane imię autora - w miejscu, gdzie mowa o włosienicy Przemysła I. Notatka ta została poczyniona ręką kopisty, a brzmi: „Scriptor huius Cronice Basco Custos

${ }^{28}$ Zob. rkps BN 3002 III, s.170 lub 181 (wg innej numeracji). W Polonie jest to skan 184.

${ }^{29}$ Zob. Brygida Kürbis, Studia nad Kronikq wielkopolska, Poznań 1952, s. 44-45.

${ }^{30}$ Tamże, s. 45.

${ }^{31}$ Tamże.

${ }^{32}$ Tamże. 
Posnan." (ciag dalszy został odcięty przez introligatora). Kronika wielkopolska jest doprowadzona aż do małżeństwa Przemysła z Lutgardą, nie urywa się - jak w poprzednich rękopisach - w środku rozdziału. Końcowa część tekstu ma brzmienie Rocznika kapituly poznańskiej. Potem następuje jeszcze jedna późniejsza zapiska o Przemyśle II (s. 457) ${ }^{33}$.

To, co znajduje się między Kronikq wielkopolska a Kronikq Janka z Czarnkowa, B. Kürbis opisuje w następujący sposób: najpierw zamieszczono tablicę genealogiczną książąt wschodnio-pomorskich, od Subisława aż do Mściwoja. Na następnej z kolei stronie mamy rodowód królów polskich, od Przemysła II począwszy. Dalej (s. 459) podane są wiadomości: De coronacione Premisli, De morte, De Wladislai expulsione itd., aż do roku 1309. Na końcu znajdują się luźne zapiski z lat 1266-1289, 1305-1331 (s. 461-463) i kroniczka z lat 1333-1368 (s. 463-467) ${ }^{34}$.

Pismo w Kronice Janka z Czarnkowa uczona określa jako „stojącą minuskułę z XV stulecia”. Zapisków znajdujących się za nią nie identyfikuje z konkretnym źródłem, pisze jedynie, że dotyczą lat 1384-1391. Zauważa, że Elegia na śmierć Kazimierza Jagiellończyka jest wpisana na s. 528-529, po czym powtarza się po kilku wolnych stronach (530-532) w wersji znacznie dłuższej ${ }^{35}$.

W 1959 r. Witold Nowodworski w swoim studium historyczno-bibliograficznym o Joachimie Lelewelu odsłonił przed nami związki tego wybitnego uczonego z Kodeksem lubińskim. Badania historyczne Lelewela koncentrowały się wokół zagadnień dotyczących dziejów powszechnych i narodowych. Odnośnie tych drugich miał on dalekosiężne zamiary: pragnął wydać Galla, porównać rękopisy kroniki Kadłubka i zając się rocznikami polskimi ${ }^{36}$. Manuskrypt lubiński, zawierający szereg zabytków dziejopisarstwa polskiego, mógł w niemałym stopniu przysłużyć się do realizacji tych celów. Lelewel z kodeksem zetknął się w okolicznościach, u początku których legły decyzje ministra Feliksa Łubieńskiego. On to podjął zamiar utworzenia biblioteki narodowej. Dzięki swoim kontaktom pozyskiwał z klasztorów wielkopolskich w Lubiniu, Obrze, Bledzewie, Paradyżu, Trzemesznie i Przemęcie cenne druki i rękopisy, sprowadzał je do Warszawy i przechowywał w gmachu Sądu Apelacyjnego. Pieczę nad zbiorami Biblioteki przy Sądzie Apelacyjnym sprawował Mateusz Kozłowski, doświadczony bibliograf. W miarę swoich możliwości starał się

${ }^{33}$ Tamże, s. 45-46.

${ }^{34}$ Tamże, s. 46.

${ }^{35}$ Tamże.

${ }^{36}$ Zob. Witold Nowodworski, ,, Bibliograficznych ksiag dwoje” Joachima Lelewela. Studium historyczno-bibliograficzne na tle epoki, Wrocław 1959, s. 59, 62. 
on wychodzić naprzeciw zapotrzebowaniom czytelniczym warszawskich uczonych i twórców literatury. Gromadzone masowo księgi, pomimo ciasnoty biblioteki, udostępniano zainteresowanym. Do ich grona należał m.in. Lelewel, któremu Kozłowski, nie nadążający z porządkowaniem księgozbioru, zaproponował włączenie się do prac bibliotecznych. Lelewel chętnie się zgodził, ponieważ spodziewał się, że będzie to korzystne dla jego planów pisarskich. Wypadki polityczne lat 1812-1813 zniweczyły projekt utworzenia biblioteki narodowej, ale zebrane już książki ocalały z pożogi wojennej, Lelewel zaś przez cały ten czas wertował je i sporządzał notatki. Wśród rękopisów sprowadzonych do Biblioteki przy Sądzie Apelacyjnym był też XV-wieczny kodeks papierowy pochodzący z klasztoru benedyktynów w Lubiniu ${ }^{37}$.

W roku 1962 B. Kürbis dostarcza kolejnych wiadomości o rękopisie lubińskim w przedmowie do wydania Roczników wielkopolskich. W tym czasie wspomniany manuskrypt znajduje się w Bibliotece Narodowej pod sygnaturą aktualną również dzisiaj, mianowicie 3002. Badaczka dostrzega, że paginacja z XVII i XIX w. jest niedokładna ${ }^{38}$. W opisie noty proweniencyjnej ze s. 170, w której pojawiają się nazwiska „Bolęcki” i „Chabielski”, zauważa: „Nie udało się zidentyfikować tych osób” ${ }^{39}$. Kodeks, tym razem już śmiało i bez wahania, mediewistka nazywa ,rękopisem Jana Dąbrówki" - w oparciu o informacje, których udzieliła jej Zofia Budkowa. Ta zaś potwierdziła, że mistrz Jan Dąbrówka około 1440 r. na uniwersytecie krakowskim komentował Kronikę mistrza Wincentego. Komentarz zachował się w kilkunastu rękopisach. Ten, który znajduje się w kodeksie lubińskim, ma postać oryginalnego brulionu Mistrza Jana. Potwierdza to ogląd innych manuskryptów zawierających jego pismo, które zachowały się w Bibliotece Jagiellońskiej ${ }^{40}$.

Charakterystykę zawartości kodeksu B. Kürbis opiera tutaj w dużej mierze na wykazie J. Korzeniowskiego, wzbogaca jednak opis o poczatki i zakończenia utworów, których gdzieniegdzie jej poprzednik nie podał: „Rocznik małopolski - Exp.: est monachus in Andrzeyow, ubi vixit 5 annos; [...] Genealogia Piastów w formie tablic - Inc.: Gracchus primus rex Polonie. Kończy się na dzieciach Łokietka; [...] Kronika mistrza Wincentego - Exp.: sese offerebat cunctis affabilitate prestabilem; Kronika wielkopolska [...] aż do słów: ubicumque pugnaverat pro iusti-

${ }^{37}$ Tamże, s. 63.

38 Zob. MPH, seria II, t. VI: Roczniki wielkopolskie, wyd. Brygida Kürbis przy współudziale Gerarda Labudy, Jerzego Lucińskiego i Ryszarda Walczaka, Warszawa 1962, s. XXIII.

${ }^{39}$ Tamże, s. XXIV.

${ }^{40}$ Tamże. 
cia na f. $315 \mathrm{v}$; [...] Kronika Janka z Czarnkowa - Exp.: sed prohibere ipsum nolente; Luźne zapiski Wielkiej Kroniki z lat 1384-1391 - Exp.: cum quinque villis ecclesie Gneznensis". Kronikę wielkopolska uznaje za część Kroniki wielkiej. Po niej dostrzega dwie wiadomości z Rocznika kapituly poznańskiej. Zauważa jednak, że reszty tegoż rocznika tu brak, nie ma też Rocznika kapituły gnieźnieńskiej, który znajduje się w innych przekazach Kroniki wielkopolskiej. Przy zapiskach rocznikarskich z lat 1295-1307 i 1309 na f. 317-317v pisze, że środkowa część notatek jest wyjęta z Kroniki oliwskiej. Zapiski z lat 1266-1333 na f. 318-319 uznaje za tzw. Kroniczkę krakowska ${ }^{41}$.

Jacek Wiesiołowski natrafia na kodeks lubiński przy okazji badań nad kolekcjami historycznymi powstałymi na terenie Polski w XIV i XV wieku. Pierwsze zapiski na k. 1v określa jako „Spis Piastów (fragment notat brulionowych do Rodowodu książąt polskich)" ${ }^{42}$. Przy Kronice Mierzwy dostrzega podział na księgi zgodnie z kroniką Kadłubka: „,k. 7 liber 2-us; k. 13 liber tercius; k. 19 liber quartus; k. 25 rubro: finis Vincentius" ${ }^{\prime 3}$. O notatkach na k. 27-30 pisze: „Rocznik małopolski do 1202 r. oraz Noty o Kadłubku z 1208 i 1216 r. Wiadomość z 1203 r. Henricus imperator obiit skreślona. Pisane trzema rękoma, pierwszy z kopistów przepisał również Kronikę Mierzwy"44. Przy Rodowodzie ksiażat polskich (k. 30v$35 \mathrm{v})$ zaznacza: „Niektóre partie Rodowodu powtórzone w dwóch różnych ujęciach" ${ }^{45}$. Przy Kronice Mistrza Wincentego (k. 36-265) kładzie uwagę: „przepisało kilku kopistów”46. Tekst z kart 267-351v traktuje jako całość - uznaje go za Kronikę wielka. Uczony podkreśla, że ma ona osobne kustosze. Kronika wielkopolska rozpoczyna się w niej od rozdz. 12, brak natomiast Rocznika krótkiego, Kalendarza i Spominek włoctawskich, Rocznika kapituły gnieźnieńskiej, znacznych fragmentów Rocznika kapituły poznańskiej, Rocznika wielkopolskiego, Spominek gnieźnieńskich. Wcielono za to do tejże kroniki wyciagi z Kroniki oliwskiej i Tablice genealogiczne ksiązat pomorskich ułożone i zapisane być może przez samego Jana z Dąbrówki ${ }^{47}$.

Jacek Wiesiołowski odnotowuje, że Elegia na śmierć Kazimierza Jagiellończyka doczekała się już opracowań. Przy notach z lat 1226 i 1234

${ }^{41}$ Tamże, s. XXIV-XXV.

${ }^{42}$ Jacek Wiesiołowski, Kolekcje historyczne w Polsce średniowiecznej XIV-XV w., Wrocław 1967, s. 54.

${ }^{43}$ Tamże.

${ }^{44}$ Tamże.

${ }^{45}$ Tamże.

46 Tamże.

47 Tamże. 
(k. 356) słusznie podkreśla, że jest to wyciąg z Exordium ordinis Cruciferorum dokonany ręką Jana z Dąbrówki ${ }^{48}$.

Badaczowi udaje się też zidentyfikować tajemniczych Bolęckiego i Chabielskiego z noty proweniencyjnej na s. 170:

Jan Bolęcki herbu Prus był doktorem medycyny, kanonikiem poznańskim i archidiakonem pszczewskim w 1529 r. Miejsca studiów nie udało się ustalić. Szymon Chabielski herbu Wieniawa pochodził z Chabielic z ziemi sieradzkiej. Wpisał się na Uniwersytet Krakowski w 1491 r. 7 X jako Simon Mathie de Chabyelino dioc. Posnaniensis wpłacając 5 gr. W dwa lata później występuje jako świadek w sądzie rektorskim. Był kanonikiem gnieźnieńskim od 1522 r., scholastykiem od 1538 r., kanonikiem poznańskim od 1525 r., archidiakonem śremskim 1527 r., kustoszem 1540 r., kanonikiem kolegiaty NMP w Poznaniu i krakowskim 1539 r., proboszczem kieleckim i głuszyńskim, plebanem w Czerlejnie do 1529 r., Latowiczu do 1542 r. i Solcu. Zmarł 19 listopada $1552 \mathrm{r}$. W kręgu kapituły poznańskiej nadawano mu przydomek Senior w odróżnieniu od drugiego Szymona Chabielskiego, również kanonika poznańskiego ${ }^{49}$.

Cały rękopis lubiński Wiesiołowski dzieli na trzy części. Pisze, że osnową pierwszej z nich jest kolekcja franciszkańska - Kronika Mierzwy i Rocznik małopolski. Za drugą część uznaje kronikę Kadłubka z brulionem komentarza, za trzecią - Kronike wielka, na wolnych kartach której dopisano wyciagi z źródeł oliwskich, powiązane z przekazem Kroniki wielkiej oraz najpóźniejszym z utworów zawartych w kodeksie - Elegia na śmierć Kazimierza Jagiellończyka ${ }^{50}$.

Uczony sporo miejsca poświęca drugiej części kodeksu i jej związkom z innymi rękopisami zawierającymi dzieło Kadłubka. Stwierdza, że manuskrypt lubiński jest ostatnim odpisem tekstu kroniki Mistrza Wincentego nieposiadającym komentarza. Tym określeniem nie można bowiem nazwać brulionu, który Mistrz Jan z Dąbrówki sporządził na marginesach kodeksu. Porównanie kroniki z jej tzw. bibliotecznymi rękopisami kroniki wykazuje, że kodeks lubiński jako kolekcja nie jest podobny do wspomnianych manuskryptów. Mistrz Dąbrówka albo nie dysponował rękopisem zawierającym kolekcję historyczną w momencie zamówienia

${ }^{48}$ Tamże. Wspomniane opracowania Elegii na śmierć Kazimierza Jagiellończyka to: Jerzy Łanowski, Laurentiusa Corvinusa pochwała Polski i Krakowa, „Meander” 17(5):1962, s. 270-271; Ryszard Gansiniec, Sbigneis Mikołaja Kotwica, „Pamiętnik Literacki" 48(2):1957, s. 108-130.

${ }^{49}$ J. Wiesiołowski, dz. cyt., s. 54-55.

${ }^{50}$ Tamże, s. 55. 
odpisu tekstu kroniki, albo też polecił skopiować z klocka rękopiśmiennego wyłącznie dzieło Wincentego. To niezależne stanowisko kroniki Kadłubka w kolekcji lubińskiej dowodzi, że utwór ten w rękopisie stanowi jego odrębną drugą część. Kronika Kadłubka z kodeksu lubińskiego jest jednocześnie najwcześniejszym z przekazów tekstu zawierających komentarz napisany przez Jana z Dąbrówki. Wpływ tego mistrza na rozpowszechnienie dzieła Mistrza Wincentego był ogromny. Na 33 znane rękopisy tylko cztery (nie licząc lubińskiego) nie są komentowane, a dwa z nich są późniejsze od opracowania Dąbrówki. Wnioskując z ilości zachowanych egzemplarzy, kronika Kadłubka, zanim wziął ją na warsztat Jan z Dąbrówki, cieszyła się podobna poczytnością co kronika Galla Anonima. Powstaje więc pytanie, czy kodeks lubiński, którego jeden z członów stał się tak popularny, miał wpływ na kolekcje zawierające komentowaną kronikę .

Marian Zwiercan przedstawia swój opis kodeksu w wydanej w 1969 r. pracy Komentarz Jana z Dąbrówki do Kroniki mistrza Wincentego. Według uczonego rękopis składa się z dwóch części. Część I, obejmująca k. 1-35, jest zbudowana z trzech składek: dwu seksternionów i kwinternionu, bez kustoszy i reklamantów. Rozpoczyna się ona tablicą genealogiczną Piastów, a kończy Rodowodem ksiązat polskich. Część II liczy 19 składek oznaczonych kustoszami. Ze względu na układ treści można ją podzielić na dwie podczęści. Pierwsza z nich mieści się na k. 36-266 i składkach oznaczonych kustoszami 1-11 (w obrębie całego kodeksu są to składki IV-XIV), o różnorodnej objętości - od decernionów do seksternionów, powiększonych dodanymi kartami i karteczkami różnego formatu. Zawiera Kronikę mistrza Wincentego z brulionem komentarza Jana z Dąbrówki. Druga z podczęści, k. 267-356, obejmuje składki XV-XXII całości kodeksu, oznaczone kustoszami 12-18 (ostatnia bez kustosza). Ta podczęść mieści Kronikę wielka ${ }^{52}$.

Ogląd poszczególnych utworów M. Zwiercan wzbogaca o następujące uwagi. Na marginesach Kroniki Mierzwy (Dzierzwy) kopista pomieścił hasła treściowe, zaś Jan z Dąbrówki - glosy. Mamy tu do czynienia z podziałem tekstu według Kroniki mistrza Wincentego; na marginalia składają się wynotowane $\mathrm{z}$ tekstu daty (zwłaszcza te po roku 1202), imiona ważnych osobistości, fakty i zdarzenia, niekiedy objaśnione jest znaczenie słów. W Roczniku małopolskim wyróżniamy trzy ręce: ręką kopisty tzw. Kroniki Dzierzwy zostały przepisane zapiski z lat 899-1061 (k. 27r-

${ }^{51}$ Tamże, s. 66.

${ }^{52}$ Zob. M. Zwiercan, Komentarz Jana z Dabrówki do Kroniki mistrza Wincentego zwanego Kadlubkiem, Wrocław 1969, s. 13-15. 
28v), ręką Dąbrówki - zapiski z lat 1070-1095, 1208 i 1216 (k. 28v-30r) oraz anonimową ręką - zapiski z lat 1100-1202, a także początek wiadomości z 1203 r. (k. 28v-30r). Charakterystyczne jest to, że Rocznik matopolski urywa się na roku 1202, tj. dacie zakończenia kroniki Kadłubka. Uczony widzi w tym ślad celowej działalności Mistrza Jana, pod którego nadzorem i przy którego pomocy zostały przepisane wymienione źródła historyczne. Pismo obu wspomnianych kopistów odnajdujemy w dalszej części omawianego kodeksu oraz w rękopisie BJ 479, mieszczącym Policraticus Jana z Salisbury, dzieło skopiowane w roku 1435 dla Jana Dąbrówki. Pierwszy Rodowód ksiażat polskich, pomieszczony na k. 34v$35 \mathrm{v}$, a zakończony na k. 34r, zaczyna się od Kraka i jest doprowadzony do prawnuków Władysława Łokietka. Ostatnich jego potomków oznaczono literami A i B. Spis ten pochodzi sprzed połowy XV wieku, na co wskazuje charakter pisma Jana z Dąbrówki. Drugi Rodowód ksiażąt polskich, uwzględniający w sposób szczególny mazowiecką linię Piastów, został wpisany na k. 30v-33r w roku 1462 lub po nim. Na początku mamy wymienionego Kraka, podobnie jak w spisie pierwszym, na końcu zaś książąt płockich: Ziemowita VI (VII) i Władysława II, z odnotowaniem ich śmierci w roku 1462, oraz synów Bolesława IV, księcia warszawskiego. Podczas spisywania drugiego Rodowodu autor uzupełnił niektóre dane w pierwszym, wcześniejszym. Przy notowaniu Komentarza do Kroniki mistrza Wincentego na kartach 43r-43v i 49v-54r Dąbrówka posłużył się kopistą. Jego pismo jest podobne do ręki w pierwszej części kodeksu, kończącej Rocznik małopolski. To kursywa z dużą ilość skreśleń, poplamień, niekiedy nie dokończonych wyrazów. Fakt ten wskazuje, że kopista pisał pod dyktando autora. Ten zaś obok jego tekstu pozostawił swoje uzupełnienia. Układ tekstu kroniki i komentarza jest następujący: wstęp do komentarza, k. 36r -37v; prolog, k. 37v-43r, 44r-46v; księga I, k. 43r-43v, 47r-69v; księga II, k. 70r-126v i 128r; księga III, k. 128 $\mathrm{r}-128 \mathrm{v}, 127 \mathrm{r}-127 \mathrm{v}, 128 \mathrm{v}-176 \mathrm{v}$ i 180r; i wreszcie księga IV, k. 180r-180v, 176v-179v, 180v-265v. Tekst drugiej podczęści (Kronika wielka), poza małymi fragmentami pochodzącymi od anonimowych kopistów (k. 303 r-303v, 314r-314v i 310r-312v) oraz Kronika Janka z Czarnkowa, został przepisany przez Jana z Dąbrówki. On też wynotował na marginesach daty pojawiające się w tekście Kroniki wielkopolskiej, imiona ważniejszych osobistości i fakty, a ponadto oznaczył podział tekstu według Kroniki Wincentego oraz dał odsyłacze do jej rozdziałów w księdze IV. Uzupełnił także opuszczenia tekstu zaczerpniętego przez Kronikę wielkopolska z kroniki Kadłubka, np. w rozdz. 20. Kronika Janka z Czarnkowa rozpoczęta była przez Mistrza Jana, a kontynuowana i dokończona przez 
dwu anonimowych kopistów. Na jej marginesach i na marginesach Kroniki krakowskiej spotykamy daty, niektóre imiona osób oraz zdarzenia opisywane w tekstach, wypisane ręką samego Jana z Dąbrówki. Tu też znajdują się tak lubiane przez niego zapiski genealogiczne, m.in. o Ziemomyśle, księciu kujawskim, oraz jego synach i wnuku Władysławie Białym, księciu gniewkowskim, a także o Ziemowicie III (IV) Starszym i jego synach ${ }^{53}$.

Wiersz Corvinusa M. Zwiercan uznaje za wpisany już po śmierci Mistrza Jana (styczeń 1472 r.). Odnotowuje też edycję utworu dokonaną przez Jerzego Krókowskiego w 1962 roku $^{54}$. Odnośnie wyciagu z Exordium ordinis Cruciferorum uczony dostrzega, że w pracach J. Korzeniowskiego i B. Kürbis został pominięty fragment tekstu. Po słowach ,et Swantopelcus Pomeranie et fundaverunt” powinno być jeszcze: „,castrum et Civitatem Culmensem et post hec intraverunt"'55.

W znaczący sposób M. Zwiercan przyczynia się do oznaczenia czasu, w którym powstał kodeks, a to dzięki zidentyfikowaniu znaków wodnych wykonanych przy produkcji papieru. Znaki te są różnorodne: głowa wołu z rozeta, głowa wołu z gwiazda, dwa klucze, głowa wołu z krzyżem, głowa wołu z rozetą i trójkątem u pyska. Podobizny niektórych z nich uczony odnalazł w pracach Franciszka K. Piekosińskiego, Nikolaja P. Lichačeva, Charlesa-Moïse'a Briqueta i na tej podstawie ustalił, że manuskrypt powstał w latach trzydziestych XV wieku ${ }^{56}$.

Marian Zwiercan także lepiej od swoich poprzedników odczytuje skróty w notce proweniencyjnej i proponuje nową wersję jej drugiej części: „Viginti numero inclusis quattuor libris in humanioribus Simoni Chabielski nepoti datis" 57 . Notkę na k. 25r, którą Wiesiołowski odczytał jako „Finis Vincentius”, słusznie radzi odczytywać jako „Finis Wincenciane" 58 .

Przy okazji opisu noty proweniencyjnej uczony dostrzega ciekawy problem. Zauważa, że nigdzie nie wspomniano, w jaki sposób rękopis znalazł się w rękach Jana Bolęckiego. Może manuskrypt przewiózł z Krakowa do Poznania Szymon Chabielski. Obecność tak cennego dla historio-

${ }^{53}$ Tamże, s. 13-17.

${ }^{54}$ Tamże, s. 17, 18 i przyp. 23. Epicedion wydał J. Krókowski w dodatku do artykułu: Laurentius Corvinus und seine Beziehungen zu Polen [w:] Renaissance und Humanismus in Mittel- und Osteuropa. Eine Sammlung von Materialen, besorgt von J. Irmscher, Berlin 1962, Deutsche Akademie der Wissenschaften zu Berlin. Schriften der Sektion für Altertumswissenschaft, Bd. XXXII, s. 167-169.

${ }^{55}$ Zob. M. Zwiercan, dz. cyt., s. 17, przyp. 24.

${ }^{56}$ Tamże, s. 18.

${ }^{57}$ Tamże, s. 19.

${ }^{58}$ Tamże, s. 13, przyp. 5. 
grafii polskiej kodeksu w Poznaniu jest bardzo zastanawiająca, zwłaszcza W świetle tego, co wiemy o losach rękopiśmiennego księgozbioru Jana z Dąbrówki. Kolekcja ta w całości przeszła do bibliotek Uniwersytetu Krakowskiego. Tylko jeden z kodeksów, prawdopodobnie w XVII wieku, stał się własnością klasztoru św. Ducha w Krakowie, a po likwidacji tamtejszego konwentu w 1788 r. został przeniesiony do Biblioteki Kapituly Krakowskiej $j^{59}$.

Wojciech Drelicharz uwagi o kodeksie lubińskim włączył do wydanej w 2003 r. pracy o annalistyce małopolskiej w XIII-XV wieku. Opracowanie to stanowi syntezę wszystkich podawanych dotychczas wiadomości, której zaleta jest duża przejrzystość i pogrupowanie danych według następującego schematu: Wcześniejsze opisy kodeksu, Opis kodeksu, Układ zawartości kodeksu, Opis wybranych części kodeksu, Twórca kodeksu, Geneza i dzieje kodeksu ${ }^{60}$.

W Układzie zawartości kodeksu uderza fakt, że badacz spis Piastów z k. 1v uznaje za I redakcję Rodowodu ksiażąt polskich, to zaś, co mamy na k. 30v-33r, za III redakcję, a zapiski z k. 34r-35v - za II redakcję ${ }^{61}$. Tym redakcjom więcej miejsca poświęca $\mathrm{w}$ dalszej części pracy. Pisze tam między innymi, że redakcja I Rodowodu ksiażat polskich jako ostatnich wylicza synów Kazimierza - księcia kujawskiego i łęczyckiego. Redakcja II dzieła została zamieszczona na k. 34r-35v, ale kolejność tekstu jest inna niż kolejność stron: tekst zaczyna się na k. 34v i ciagnie się do k. 35v, a kończy się, paradoksalnie, na k. 34r, a więc na stronie, która poprzedza początek tej redakcji Rodowodu. Redakcja ta jako ostatnich wymienia prawnuków Władysława Łokietka (fol. 34r), jednak pierwotny jej koniec zbiegał się z końcem fol. 35v, tam zaś zapiski zamykają się na ostatnich Piastach kujawskich: Kazimierzu Wielkim, Elżbiecie Łokietkównie i Władysławie Białym. Redakcja III Rodowodu ksiażat polskich kończy się na synach Bolesława mazowieckiego: Konradzie, Kazimierzu, Bolesławie i Januszu oraz synach Władysława (I zachodniomazowieckiego): Siemowicie (VI) i Władysławie II, którzy zmarli bez potomstwa (k. 33r $)^{62}$.

W Opisie wybranych części kodeksu W. Drelicharz zajmuje odmienne niż M. Zwiercan stanowisko odnośnie ręki kopisty we fragmentach $K o$ mentarza $\mathrm{z}$ k. 43r-43v i 49v-54 r. Zauważa, że ręka kopisty, który wpisał

${ }^{59}$ Tamże, s. 20.

${ }^{60}$ Zob. W. Drelicharz, Annalistyka małopolska XIII-XV wieku. Kierunki rozwoju wielkich roczników kompilowanych, Kraków 2003, s. 65, 66, 67, 68,69.

${ }^{61}$ Tamże, s. 66.

${ }^{62}$ Tamże, s. 68. 
noty Rocznika matopolskiego z lat 1100-1202 (k. 27v-29v), nie pojawia się więcej w kodeksie i nie jest ona tożsama $\mathrm{z}$ ręką anonimowego kopisty fragmentu Komentarza Jana z Dąbrówki. Pismo to, zdaniem badacza, wcale nie jest podobne do występującego w pierwszej części kodeksu, a kończącego Rocznik małopolski ${ }^{63}$.Wojciech Drelicharz słusznie też zauważa, że zapiska o Mistrzu Wincentym podana pod rokiem 1216 na końcu Rocznika małopolskiego w rzeczywistości dotyczy roku $1218^{64}$.

W części Twórca kodeksu badacz postarał się podać powody, dla których Jan z Dąbrówki gromadził wspomniane zabytki polskiej historiografii. Uznał go za miłośnika historii, kolekcjonera źródeł historycznych i wreszcie za historiografa. Podkreślił, że był autorem kilku dzieł historiograficznych. Z nich najwyżej ocenił Komentarz do Kroniki mistrza Wincentego zwanego Kadtubkiem, napisany w latach 1431-1434 z zamiarem połączenia wykładu retoryki z objaśnianiem Kadłubkowego wykładu dziejów ojczystych ${ }^{65}$.

Tu też W. Drelicharz wskazuje, kiedy brulion-autograf Jana z Dąbrówki posłużył do powstania ostatecznej redakcji Komentarza. Stwierdza, że było to w latach 1435-1436, a najprawdopodobniej - w lutym lub we wrześniu $1436 \mathrm{r}$. Wtedy to, ze słów podyktowanych kopistom przez Jana z Dąbrówki, korzystającego z brulionu powstał czystopis. Zachował on się do naszych czasów aż w czterech kopiach. Tak więc rok 1436 stanowi datę ostatecznego zredagowania Komentarza Jana z Dąbrówki ${ }^{66}$.

W części Geneza i dzieje kodeksu badacz opisał kolejność, w jakiej były grupowane w kodeksie poszczególne zabytki. Na podstawie znaków wodnych papieru, pisma oraz kustoszy składek wywnioskował, że najwcześniej skopiowano tekst Kroniki mistrza Wincentego. Dopiero później kopiści współpracujący z Dąbrówką oraz on sam przepisali Kronikę Dzierzwy, Rocznik małopolski Dąbrówki, Kronikę wielkopolska i drobniejsze wypisy z Kroniki wielkiej. Sposób wykorzystania źródeł w Komentarzu wskazuje, że Jan z Dąbrówki początkowo starał się pomieścić tu jak największe fragmenty przydatnych mu pomników historiograficznych i dopiero w trakcie tych prac zdecydował się skopiować je in extenso do kodeksu, poza właściwym Komentarzem ${ }^{67}$.

Jeśli chodzi o losy kodeksu, W. Drelicharz wyróżnił następujące etapy:

\footnotetext{
${ }^{63}$ Tamże, s. 67.

${ }^{64}$ Tamże.

${ }^{65}$ Tamże, s. 69.

${ }^{66}$ Tamże.

${ }^{67}$ Tamże, s. 70.
} 
1) własność Jana z Dąbrówki (do 1472 r.),

2) własność bibliotek Uniwersytetu Krakowskiego (1472-?),

3) własność Szymona Chabielskiego (1492?-?),

4) własność Jana Bolęckiego (?-1538),

5) własność klasztoru benedyktynów w Lubiniu (1538-1811),

6) własność Biblioteki przy Sądzie Apelacyjnym w Warszawie (18111817),

7) własność Biblioteki Publicznej przy Uniwersytecie Warszawskim (1817-1831),

8) własność Cesarskiej Biblioteki Publicznej w Petersburgu (18311921),

9) własność Biblioteki Narodowej w Warszawie (od 1921 r. do chwili obecnej) $)^{68}$.

Badacz dokładnie opisał wojenne i powojenne perypetie manuskryptu. Przed wybuchem wojny został on ukryty w kazamatach fortu Sokolnickiego na Żoliborzu i tak przetrwał oblężenie Warszawy we wrześniu 1939 r. W maju 1944 r. znalazł się w jednej z sześciu skrzyń z częścią najcenniejszych rękopisów Biblioteki Narodowej. Skrzynie te umieszczono, staraniem polskiego personelu, w piwnicach Biblioteki Ordynacji Zamoyskich, aby zabezpieczyć je przed zbliżającym się frontem. Tak kodeks uniknął zagłady w Bibliotece Krasińskich, która została spalona przez Niemców po stłumieniu powstania warszawskiego w październiku $1944 \mathrm{r}$. Trzeba tu nadmienić, że na polecenie władz okupacyjnych w lipcu 1941 r. zostały tam złożone rękopisy Biblioteki Narodowej, scalonej przez Niemców z Biblioteką Krasińskich i Biblioteką Uniwersytetu w jedną Staatsbibliothek Warschau. W grudniu 1944 r. wspomniane skrzynie Niemcy wywieźli do Görbitsch pod Frankfurtem nad Odrą. Manuskrypt uniknął rabunku podczas rozkradania tego transportu. Część księgozbioru odnalazła polska ekspedycja, drugą zaś - przejęła i wywiozła do Moskwy armia sowiecka. Stamtąd rękopisy powróciły do Polski w 1948 roku $^{69}$.

Podobnie syntetyczny charakter ma nota o kodeksie w Inwentarzu rękopisów do połowy XVI wieku w zbiorach Biblioteki Narodowej, opracowanym przez Jerzego Kaliszuka i Sławomira Szyllera, wydanym w 2012 r. Znajdujemy tam następujące informacje: opis fizyczny, zawartość kodeksu, proweniencję, sygnatury dawne, bibliografię, sygnaturę mikrofilmu. Wykaz zawartości kodeksu oparty na ustaleniach poprzednich badaczy, którzy zostali wymienieni w niniejszym artykule, przedstawia się tu następująco:

\footnotetext{
${ }^{68}$ Tamże, s. 70-71.

${ }^{69}$ Tamże, s. 71-72.
} 
1) K. 1v: Tablica genealogiczna Piastów, Katalog biskupów krakowskich.

2) K. 2r-27r: Kronika Dzierzwy.

3) K. 27r-30r: Rocznik małopolski.

4) K. 30v-33r: Rodowód ksiażat polskich - redakcja III.

5) K. 34r-35v: Rodowód ksiażat polskich - redakcja II.

6) K. 36r-265v: Vincentius dictus Kadłubek, Chronica cum commentario Ioannis de Dambrowka.

7) K. 267r-316r: Kronika wielkopolska.

8) K. 316r-v: Genealogia ksiażat wschodniopomorskich i Katalog królów polskich.

9) K. 317r: zapiski rocznikarskie z lat 1295-1305 z Rocznika kapituły poznańskiej.

10) K. 317v: Kronika oliwska (fragm. - lata 1305-1310).

11) K. 318r-319r: Kronika katedralna krakowska (fragm. - lata 12661289, 1305-1368).

12) K. 319r-351r: Ioannes de Czarnków, Chronica.

13) K. 351r-351v: Spominki gnieźnieńskie (fragm. - lata 1384-1392).

14) K. 351v-355r: Laurentius Corvinus, Epicedion elegiacum penthametrum.

15) K. 356r: Exordium ordinis Cruciferorum (wyciag Jana Dąbrówki za lata 1226 i 1234$)^{70}$.

W niniejszej pracy prześledziliśmy starania polskich badaczy zmierzające do ustalenia zawartości i losów kodeksu lubińskiego. Nie brakło na tej drodze, jak to nieraz bywa w nauce, błędów, pomyłek i mylnych hipotez, jednakże ogląd tego samego zabytku dokonany okiem wielu znawców przedmiotu wyprowadził nas na właściwe tory. Duża liczba utworów zawartych we wspomnianym kodeksie doczekała się edycji. Nie ma jej jednak znajdująca się w tym manuskrypcie redakcja Komentarza do Kroniki mistrza Wincentego. Utwór ten - z racji swego układu i mało czytelnego pisma - nadal pozostaje dla uczonych „,ciemną kartą”.

${ }^{70}$ Inwentarz rękopisów do połowy XVI wieku $w$ zbiorach Biblioteki Narodowej, oprac. Jerzy Kaliszuk, Sławomir Szyller, Warszawa 2012 (Inwentarze Rękopisów Biblioteki Narodowej, 3), s. 69-70. 


\section{Streszczenie}

\section{Całościowe opracowania Kodeksu lubińskiego (poł. XIX w. - pocz. XXI w.)}

Kodeks lubiński to w głównej mierze dzieło Jana z Dąbrówki i jego kopistów. Zawiera on miscellanea historica wydobyte ze średniowiecznych zabytków polskiej historiografii bądź nakreślone przez Jana doraźnie, na użytek własny. Obok kopii takich dzieł, jak Kronika Dzierzwy, Kronika polska Mistrza Wincentego tzw. Kadlubka, Kronika wielkopolska, Kronika Janka z Czarnkowa, mamy tu też zabytek wielkiej wagi, którego autorem jest sam Jan z Dąbrówki, mianowicie brulion Commentum in Chronicam Polonorum Magistri Vincentii dicti Kadlubek. Wśród tego znajdują się też mniejsze jego opuscula, jak np. trzy redakcje Rodowodu ksiażat polskich i Katalog biskupów krakowskich, a także excerpta $\mathrm{z}$ różnych pomniejszych dzieł kronikarskich i rocznikarskich. Identyfikacja tych dzieł trwała przez blisko półtora wieku i często nie była wolna od błędnych hipotez. Celem artykułu jest pokazanie, jak narastała wiedza dotycząca zabytku i jak stopniowo, drogą żmudnych dociekań dochodzono do właściwych wniosków. Analizowane są tu całościowe opracowania kodeksu, które wyszły spod pióra polskich historyków i bibliotekarzy takich jak August Bielowski, Jan Szlachtowski, Józef Korzeniowski, Witold Nowodworski, Brygida Kürbis, Jacek Wiesiołowski, Marian Zwiercan, Wojciech Drelicharz, Jerzy Kaliszuk i Sławomir Szyller. Z nich najbardziej kluczowe dla całości badań wydają się dziś konstatacje Józefa Korzeniowskiego i Mariana Zwiercana. Artykuł ten ma być pomocą dla tych, którzy będą korzystać ze skanu kodeksu lubińskiego, który niedawno został zamieszczony w Narodowej Bibliotece Cyfrowej zwanej Poloną. Wpisuje się też w nurt mediewalizmu, tj. nauki zajmującej się obecnością i funkcjonowaniem średniowiecza w pracach autorów późniejszych.

\section{Summary}

\section{Descriptions of the Lubiński Manuscript, mid- $19^{\text {th }}$ - early $21^{\text {st }}$ Centuries}

The Lubiński Codex was created in the first half of the $15^{\text {th }}$ century, predominantly by the efforts of Jan of Dąbrówka and his scribes. It comprises miscellaneous historical writings, found by Dąbrówka in older manuscripts, or sketched for current use by himself. Beside works by established authors, such as the chroniclers Wincenty Kadłubek, Dzierzwa, or Janko of Czarnków, and the Wielkopolska Chronicle, one can find there Dąbrówka's own opus magnum, his Commentary to the Chronicle of Wincenty Kadlubek. Apart from these major writings the Lubiński Codex encompasses also his smaller pieces, like the three 
redactions of the Lineage of the Polish Princes, the Catalogue of the Bishops of Cracow, and excerpts from various chronicles and annals. The identification of these writings took over a century and a half, and was not free of erroneous conjectures. Dorota Gacka demonstrates how the work on the Lubiński Codex progressed, and how the contemporary views were gradually elaborated. The analysis encompasses only the attempts at describing and interpreting the codex as a whole, and scrutinises the consecutive efforts of a number of Polish historians and librarians, from the nineteenth through early twenty-first century. The article aims at facilitating further researches on the codex, now available in digitalised form in the CBN Polona, but it is also a contribution to medievalism, i.e. studies on the presence and functioning of the Middle Ages in the writings of later authors. 